\title{
Characterization of lignocellulose of Erianthus arundinaceus in relation to enzymatic saccharification efficiency
}

\author{
Masaomi Yamamura', Soichiro Noda1, Takefumi Hattori, ${ }^{1, a}$, Amiu Shino², \\ Jun Kikuchi ${ }^{2}$, Keiji Takabe ${ }^{3}$, Shuichiro Tagane ${ }^{4}$, Mitsuru Gau ${ }^{5}$, Naohiro Uwatoko ${ }^{5}$, \\ Masahiro Mii ${ }^{6}$, Shiro Suzuki ${ }^{1}$, Daisuke Shibata ${ }^{7}$, Toshiaki Umezawa ${ }^{1,8, *}$ \\ ${ }^{1}$ Research Institute for Sustainable Humanosphere, Kyoto University, Uji, Kyoto 611-0011, Japan; ${ }^{2}$ RIKEN Plant Science \\ Center, Yokohama, Kanagawa 230-0045 Japan; ${ }^{3}$ Graduate School of Agriculture, Kyoto University, Sakyo-ku, Kyoto \\ 606-8502, Japan; ${ }^{4}$ Faculty of Sciences, Kyushu University, Fukuoka 812-8581, Japan; ${ }^{5}$ NARO Kyushu Okinawa Agricultural \\ Research Center, Koshi, Kumamoto 861-1192, Japan; ${ }^{6}$ Graduate School of Horticulture, Chiba University, Matsudo, Chiba \\ 271-8510, Japan; ${ }^{7}$ Kazusa DNA Research Institute, Kisarazu, Chiba 292-0818, Japan; ${ }^{8}$ Institute of Sustainability Science, \\ Kyoto University, Uji, Kyoto 611-0011, Japan \\ *E-mail: tumezawa@rish.kyoto-u.ac.jp Tel: +81-774-38-3625Fax: +81-774-38-3682
}

Received May 7, 2012; accepted November 27, 2012 (Edited by T. Aoki)

\begin{abstract}
Lignin is a major component of the secondary cell walls of vascular plants, and an obstacle in the conversion of plant cell wall polysaccharides into biofuels. Erianthus spp. are large gramineous plants of interest as potential energy sources. However, lignocelluloses of Erianthus spp. have not been chemically characterized. In this study, we analysed lignins, related compounds, enzymatic saccharification efficiencies, and minerals in the ash of the inner and outer parts of the internode, leaf blade and leaf sheath of Erianthus arundinaceus. Lignins in four organs consisted of guaiacyl, syringyl, and $p$-hydroxyphenyl units. The ratios of syringyl to guaiacyl lignins and lignin contents ranged from 0.43 to 0.79 and 20 to $28 \%$, respectively, with values highest in the outer part of the internode. The amounts of ferulic acid were similar (7.3-11.8 $\mathrm{mg} \mathrm{g}^{-1} \mathrm{dry}$ weight of cell-wall material) in all four organs, while there was more $p$-coumaric acid in the inner part of the internode $\left(44.7 \mathrm{mg} \mathrm{g}^{-1}\right.$ dry weight of cell-wall material) than in other organs $\left(25.7-28.8 \mathrm{mgg}^{-1}\right.$ dry weight of cell-wall material). The enzymatic saccharification efficiency ( $24 \mathrm{~h}$ reaction time) of the leaf blade was $21.6 \%$, while those of the other organs ranged from 10.0 to $15.2 \%$. The leaf blade had the highest ash content (17.1\%); the main inorganic element was silicon. This paper provides the first fundamental knowledge of $E$. arundinaceus lignins.
\end{abstract}

Key words: Enzymatic saccharification, Erianthus arundinaceus, lignin, lignocellulose.

Lignin is a complex phenylpropanoid polymer and a major component of plant cell walls. This compound is biosynthesized via oxidative coupling of $p$-hydroxycinnamyl alcohols (monolignols) and related compounds that are formed in the cinnamate/ monolignol pathway (Umezawa 2010). Lignin fills the spaces between cell wall polysaccharides and confers mechanical strength and imperviousness to the cell wall (Boerjan et al. 2003). Lignin biosynthesis is closely tied to the evolution of land plants; there is no true lignin in algae and bryophytes, unlike in tracheophytes (pteridophytes, gymnosperms, and angiosperms) (Sarkanen and Hergert 1971), except for an example of lignin detection in red algae (Martone et al. 2009). However, the inherent characteristics of lignin present obstacles to chemical pulping, forage digestion, and enzymatic hydrolysis of plant cell wall polysaccharides for biorefinery. Thus, lignin biosynthesis has been studied with the goal of producing beneficial plant materials.

Recently, because of the increased demand for bioethanol as an alternative to fossil fuels, the lignocelluloses of energy-producing plants are being intensively investigated. Current bioethanol production depends largely on sugar cane and corn. Brazil and the United States exploit sugar cane and corn, respectively, and they together account for about $70 \%$ of the world bioethanol production (Balat et al. 2008). Then, the industry is rapidly expanding as about $40 \%$ of the corn produced in the US goes to ethanol production (http:// www.ers.usda.gov/Data/FeedGrains/), increasing the price of corn for feed and downstream animal products (Anderson and Akin 2008). Therefore, large gramineous plants that produce large amounts of biomass but are not used for food are drawing attention as potential materials for biofuel and industrial feedstock production.

Erianthus spp., large energy-producing plants, belong

a Present address: Institute of Socio-Arts and Sciences, The University of Tokushima, Tokushima, Tokushima 770-8502, Japan.

This article can be found at http://www.jspcmb.jp/

Published online March 19, 2013 
to the tribe Andropogoneae, under the grass family Gramineae (Amalraj et al. 2008). Members of this genus are perennial grasses and are used worldwide as breeding material for sugarcane, a close relative (Nair et al. 2005; Hattori et al. 2010). Erianthus spp. show better growth even under unfavorable environmental conditions, such as submersion, acidic soil, and dry-season soil drought (Matsuo et al. 2002). In addition, Erianthus spp. yield huge amounts of biomass; the yearly dry-matter yield is in the range of 40 to 60 ton $\mathrm{ha}^{-1} \mathrm{yr}^{-1}$ (Mislevy et al. 1997; Hattori and Morita 2010). This yield is higher than that of other energy-producing plants, e.g., $12-40 \mathrm{tha}^{-1} \mathrm{yr}^{-1}$ in Miscanthus spp. and $7-35 \mathrm{tha}^{-1} \mathrm{yr}^{-1}$ in switchgrass (Hattori et al. 2010). For these reasons, Erianthus spp. are receiving much attention as a potential biofuel and industrial feedstocks.

Surprisingly, despite the importance of Erianthus spp. as a feedstock, detailed chemical analyses of its cell-wall constituents have not been reported. In gramineous plants, it is known that enzymatic hydrolysis or saccharification of the cell wall is inhibited not only by lignin but also by ferulic acid (Grabber et al. 1998a, 1998b), which cross-links lignin and polysaccharides. Moreover, the states of being of their compounds in the cell wall vary among plant species and even among organs within a single plant species. Therefore, to exploit the potential of Erianthus spp., we must analyse lignins and cell-wall linked $p$-hydroxycinnamic acids.

In this study, we selected Erianthus arundinaceus (Retz.) Jeswiet, which can be cultivated in Japan (Tagane et al. 2011; Uwatoko et al. 2011) as a plant material. We characterized lignins, $p$-hydroxycinnamic acids, enzymatic saccharification efficiencies, and minerals in ash in different organs of the plant and discussed the relation between the cell-wall components and enzymatic saccharification efficiencies.

\section{Materials and methods}

\section{Plant materials}

Erianthus sp., which was maintained at Kamigamo Experimental Station, Field Science Education and Research Center (FSERC), Kyoto University, Japan, was used as a plant sample. This species was identified as Erianthus arundinaceus (Retz.) Jeswiet based on the flow cytometric analysis of a polyploidy $(2 n=60)$, and morphological characteristics (Amalraj and Balasundaram 2006; Jackson and Henry 2011).

The aerial parts of E. arundinaceus (about $4.0-4.5 \mathrm{~m}$ in height) were harvested, and naturally seasoned for two months in the room. Leaf blades, leaf sheaths and stems were collected separately. We numbered internodes from the bottom to the top with the bottom internode as the 1 st. The 1st internodes $(1.6-1.7 \mathrm{~cm}$ in diameter, $16-19 \mathrm{~cm}$ in height), leaf blades, and leaf sheaths were used for lignin, $p$-hydroxycinnamic acids, enzymatic saccharification, and NMR analyses. To measure ash, the basal internodes (1st-5th internodes), leaf blades, and leaf sheaths from another tiller were used.

In addition, E. arundinaceus, which was grown at Kamigamo Experimental Station, FSERC, Kyoto University, was transplanted by division and maintained in a nursery of the Research Institute for Sustainable Humanosphere, Kyoto University. For histochemical analyses, a current-year shoot of E. arundinaceus (about $3 \mathrm{~m}$ in height) grown at the nursery was harvested and used.

\section{Chemicals}

$\left[\mathrm{OC}^{2} \mathrm{H}_{3}\right]$ Vanillin and $\left[\mathrm{OC}^{2} \mathrm{H}_{3}\right]$ syringaldehyde were synthesized previously (Sakakibara et al. 2003). All other reagents were obtained from Nacalai Tesque Inc. (Kyoto, Japan) or Wako Pure Chemicals Co., Ltd. (Osaka, Japan) unless otherwise noted.

\section{Instrumentation}

The sections prepared from each organ of E. arundinaceus were observed under a light microscope (Olympus BX51 microscope, Olympus Co., Tokyo, Japan) and images were obtained using a digital camera (Olympus DP70, Olympus Co., Tokyo, Japan) connected to the microscope.

Gas chromatography-mass spectrometry (GC-MS) analysis was performed using a Shimadzu QP-5050A GC-MS system (Shimadzu Co., Ltd., Kyoto, Japan). The GC-MS conditions were as follows: Shimadzu HiCap CBP10-M25-025 column $(25 \mathrm{~m} \times 0.22 \mathrm{~mm})$; carrier gas, helium; injection temperature, $230^{\circ} \mathrm{C}$; oven temperature, $40^{\circ} \mathrm{C}$ at $t=0$ to $2 \mathrm{~min}$, then to $230^{\circ} \mathrm{C}$ at $40^{\circ} \mathrm{C} \mathrm{min}^{-1}$; ionization, electron-impact mode $(70 \mathrm{eV})$.

Ultraviolet and visible absorbance was measured with a UV1600PC UV-visible spectrophotometer (Shimadzu Co., Ltd., Kyoto, Japan), and a SH-1000 Lab Microplate Reader (Corona Electric Co., Ltd., Ibaraki, Japan).

Amounts of inorganic elements in ash were measured with a Shimadzu EDX-700 X-ray fluorescence spectrometer. The parameters used for X-ray fluorescence were as follows: voltage, $50 \mathrm{kV}$; electric current, $100 \mu \mathrm{A}$; and integral time, $100 \mathrm{~s}$ (realtime mode). The measurements were carried out in air mode.

The NMR spectra were recorded on an Advance-700 spectrometer (Bruker, Billerica, MA, USA), equipped with an inverse triple resonance CryoProbe with a $Z$-axis gradient for 5-mm sample diameters operating at $700.153 \mathrm{MHz}$ for ${ }^{1} \mathrm{H}$ and 176.061 MHz for ${ }^{13} \mathrm{C}$.

\section{Histochemical analysis of lignin}

A small block was cut out from the 1st internode of a currentyear tiller and fixed in cold 3\% glutaraldehyde-0.1 M potassium phosphate buffer ( $\mathrm{pH}$ 7.2). After the block was washed twice with distilled water, it was placed in a $50 \%(\mathrm{v} / \mathrm{v})$ aqueous solution of Tissue-Tek O.C.T. compound (Sakura Finetek Japan, Tokyo, Japan) for $1 \mathrm{~h}$. A section ( $30 \mu \mathrm{m}$ in thickness) was cut from the block with a sliding microtome on a freezing stage. Prepared sections were subjected to phloroglucinolhydrochloric acid $(\mathrm{HCl})$ and Mäule reactions. 
The phloroglucinol- $\mathrm{HCl}$ reaction was performed by the method of Fujii et al. (1993). Briefly, the section was treated with $2 \%(\mathrm{w} / \mathrm{v})$ phloroglucinol solution in ethanol for $5 \mathrm{~min}$ at room temperature (r.t.), acidified with concentrated $\mathrm{HCl}$, and observed under the light microscope.

The Mäule reaction followed the method of Guo et al. (2001). Briefly, the section was treated with $1 \%(\mathrm{w} / \mathrm{v}) \mathrm{KMnO}_{4}$ for $5 \mathrm{~min}$, rinsed with $3 \% \mathrm{HCl}$, and the stain was developed with concentrated $\mathrm{NH}_{4} \mathrm{OH}$. Stained sections were observed under the microscope.

\section{Preparation of cell-wall material}

The 1st internode was divided into inner and outer parts with a cork borer. Four organs (inner and outer parts, leaf blade, and leaf sheath) from 3 tillers were mixed individually and disintegrated with scissors into ca. $5 \mathrm{~mm}$ long pieces. Samples were pulverized with a TissueLyser in stainless steel grinding jars with stainless steel balls (Qiagen KK, Tokyo, Japan) for $3 \mathrm{~min}$ at $25 \mathrm{~Hz}$ at r.t. The resulting powder was extracted twenty times with methanol at $60^{\circ} \mathrm{C}$. The powders were further extracted five times with hexane at r.t. and five times with distilled water at $60^{\circ} \mathrm{C}$, then freeze dried. This freeze-dried powder was referred to as cell-wall material, and was used for lignin and saccharification analyses and ash measurement.

\section{Lignin aromatic component analysis}

The aromatic substitution of the $\beta-O-4$ substructure-derived monomers was analysed by thioacidolysis (Nakatsubo et al. 2008). The aromatic substitution patterns of the $\beta-O-4$ substructure and also other substructures were analysed by alkaline nitrobenzene oxidation (Yamamura et al. 2010, 2011).

\section{Lignin content}

Lignin contents were determined by the thioglycolic acid lignin (Suzuki et al. 2009) and acetyl bromide (Hatfield et al. 1999a) methods.

\section{Cell-wall bound p-hydroxycinnamate analysis}

Cell-wall ester-linked ferulic and $p$-coumaric acids were analysed as previously described (Yamamura et al. 2011).

\section{Starch removal for saccharification analyses}

Before saccharification analyses, starch in the cell-wall material was removed by amylase treatment in a similar manner to previous reports (Hattori et al. 2012; Park et al. 2009; Wada et al. 2010). Briefly, the cell-wall material (ca. $5 \mathrm{mg}$ for the enzymatic saccharification, ca. $15 \mathrm{mg}$ for the acid saccharification) was put into a $2-\mathrm{ml}$ polypropylene screwcap microcentrifuge tube (Cat. No. 72.693.100, Sarstedt KK, Tokyo, Japan); a tube without cell-wall material was used as a control. We added to the sample $80 \%$ (v/v) ethanol ( $36 \mu \mathrm{l}$ for enzymatic saccharification, $40 \mu \mathrm{l}$ for acid saccharification) and a solution of thermostable $\alpha$-amylase (Megazyme International Ireland, Wicklow, Ireland) that had been diluted 30-fold with $100 \mathrm{mM}$ sodium acetate buffer ( $\mathrm{pH} 5.0 ; 540 \mu \mathrm{l}$ for enzymatic saccharification, $600 \mu \mathrm{l}$ for acid saccharification). The tube was heated at $100^{\circ} \mathrm{C}$ for $12 \mathrm{~min}$ with gently inverting every $4 \mathrm{~min}$. After the tube was cooled to about $40^{\circ} \mathrm{C}$, amyloglucosidase (Megazyme International Ireland) was added to the tubes $(18 \mu \mathrm{l}$ for enzymatic saccharification, $20 \mu$ l for acid saccharification). This mixture was incubated in a rotary reactor (Heatblock Rotater SN-48BN, Nissin Rika, Saitama, Japan) at $12.5 \mathrm{rpm}$ and $50^{\circ} \mathrm{C}$ for $30 \mathrm{~min}$. The tube was centrifuged $(10,000 \times \mathrm{g}, 2 \mathrm{~min})$ and the supernatant was collected to measure the amount of the liberated glucose. The residue in the tube was washed twice with $1 \mathrm{ml}$ of distilled water and twice with $1 \mathrm{ml}$ of methanol, with centrifugation $(20,000 \times g, 3 \mathrm{~min})$ after each wash. The residue was dried in vacuo for $3 \mathrm{~h}$ at r.t. (referred to as a starch-free residue), and weighed. The value after subtracting the weight of the control was used as the weight of the starchfree residue. This residue was used for enzymatic and acid saccharification analyses.

\section{Enzymatic saccharification}

The enzymatic saccharification was conducted in a similar manner as previously reported (Park et al. 2009; Hattori et al. 2012) with a slight modification. Briefly, the starch-free residue was suspended with $500 \mu \mathrm{l}$ of $50 \mathrm{mM}$ sodium citrate buffer ( $\mathrm{pH}$ 4.8 ) by vortexing for $10 \mathrm{~s}$. To the suspension was added $1 \mathrm{ml}$ of an enzyme mixture in the same buffer containing 3.3 FPU Celluclast 1.5l, 7.5 CbU Novozyme 188, and $0.205 \mathrm{mg}$ Ultraflo L (Novozymes, Bagsbaerd, Denmark). Tubes were incubated in a rotary reactor at $12.5 \mathrm{rpm}$ and $50^{\circ} \mathrm{C}$ for $2,6,14,24$, and $48 \mathrm{~h}$. The reaction was stopped by heating at $100^{\circ} \mathrm{C}$ for $10 \mathrm{~min}$ and the tubes were cooled on ice for $5 \mathrm{~min}$. After centrifugation at $20,000 \times g$ for $1.5 \mathrm{~min}, 10 \mu \mathrm{l}$ of the supernatant was mixed with $200 \mu \mathrm{l}$ of Glucose C-II Test Wako reagent (Wako Pure Chemical) and incubated at $37^{\circ} \mathrm{C}$ for $5 \mathrm{~min}$. Finally, absorbance at $505 \mathrm{~nm}$ was recorded with a microplate reader (SH-1000 Lab Microplate Reader, Corona Electric).

\section{Acid saccharification}

The starch-free residue was hydrolysed with a two-step $\mathrm{H}_{2} \mathrm{SO}_{4}$ hydrolysis method (Park et al. 2009; Wada et al. 2010; Hattori et al. 2012). Briefly, the starch-free residue was incubated in $1 \mathrm{ml}$ of $72 \%(\mathrm{w} / \mathrm{w}) \mathrm{H}_{2} \mathrm{SO}_{4}$ at $30^{\circ} \mathrm{C}$ for $1 \mathrm{~h}$. After the reaction, $150 \mu \mathrm{l}$ of the reaction mixture was transferred into fresh 2-ml polypropylene screw-cap tubes containing $1050 \mu \mathrm{l}$ of distilled water, and the suspension was heated at $100^{\circ} \mathrm{C}$ for $2 \mathrm{~h}$. After the tube was centrifuged at $20,000 \times \mathrm{g}$ for $3 \mathrm{~min}$, the supernatant was transferred into 14-ml polypropylene round-bottom tubes and neutralized with $1 \mathrm{ml}$ of $25 \%(\mathrm{w} / \mathrm{w})$ $\mathrm{CaCO}_{3}$ suspension. Separately, $1.2 \mathrm{mg}$ of glucose was treated with $\mathrm{H}_{2} \mathrm{SO}_{4}$ in the same manner to estimate degradation of glucose during the acid saccharification. The 14-ml tubes were centrifuged $(2300 \times g, 20 \mathrm{~min})$, then $500 \mu \mathrm{l}$ of the supernatant was transferred into fresh $1.5-\mathrm{ml}$ tubes, and centrifuged at $10,000 \times g$ for $1 \mathrm{~min}$. Ten microliters of the supernatant was measured using Glucose C-II Test Wako reagent as conducted in the enzymatic saccharification analysis. The amount of 
glucose liberated from the starch-free residue was worked out according to the previous reports (Wada et al. 2010; Hattori et al. 2012).

\section{Calculation of saccharification efficiency}

The enzymatic saccharification efficiency (\%) was determined by the following equation:

Enzymatic saccharification efficiency $(\%)=\frac{A}{B} \times 100$

A: Total glucose liberated by enzymatic saccharification; $B$ : Total glucose liberated by acid saccharification.

\section{Measurements of ash}

About 1 to $2 \mathrm{~g}$ of cell-wall material from each organ was weighed into a porcelain crucible. These samples were transferred into a muffled furnace set at $800^{\circ} \mathrm{C}$ and incinerated for about $17 \mathrm{~h}$. The ash content was calculated by the following equation:

$$
\text { Ash content }(\%)=\frac{\text { Ash weight }}{\text { Original sample weight }} \times 100
$$

In addition, several inorganic elements in the ash from different organs were measured with a Shimadzu EDX-700 X-ray fluorescence spectrometer (Shimadzu Co., Ltd., Kyoto, Japan).

\section{NMR analyses}

Sample preparation for solubilized lignocelluloses was similar to that described by Kim and Ralph (2010). Briefly, the dried cell-wall material was further ground in a Pulverisette 5 Ball Mill (Fritsch GmbH, Idar-Oberstein, Germany) to yield $300 \mathrm{mg}$ of stock powder. Thirty mg of ball-milled powder was mixed with $600 \mu \mathrm{l}$ of dimethyl sulfoxide (DMSO)- $d_{6}$ : pyridine- $d_{5}(4: 1)$ and heated at $50^{\circ} \mathrm{C}$ for $30 \mathrm{~min}$ in a Thermomixer Comfort (Eppendorf AG, Hamburg, Germany) and then centrifuged $(20,380 \times g, 5 \mathrm{~min})$. The supernatant was used for the NMR experiments. Sample solutions were transferred into 5-mm $\phi$ NMR tubes and subjected to NMR analysis. The temperature of all NMR samples was maintained at $313 \mathrm{~K}$. The chemical shifts were referenced to the methyl group of DMSO- $d_{6}$ at ${ }^{13} \mathrm{C}=$ 40.03 ppm and ${ }^{1} \mathrm{H}=2.582 \mathrm{ppm}$, respectively.

Two-dimensional ${ }^{1} \mathrm{H}-{ }^{13} \mathrm{C}$ Hetero-nuclear Single Quantum Coherence (HSQC) spectra were collected using echo/antiecho gradient selection (the hsqcetgp pulse program in the Bruker library). The proton $90^{\circ}$ pulse value was checked and set for each sample. In all cases, the carbon $90^{\circ}$ pulse was $9.4 \mu$ s long. Relaxation delay values of $0.8 \mathrm{~s}$ were used and 256 complex f1 $\left({ }^{13} \mathrm{C}\right)$ and 1024 complex $\mathrm{f} 2\left({ }^{1} \mathrm{H}\right)$ points were recorded with eight scans per $\mathrm{f} 1$ increment. The spectral window and offset frequency in the $\mathrm{f} 1$ dimension were $150 \mathrm{ppm}$ and $80 \mathrm{ppm}$, respectively. The spectral window in the $\mathrm{f} 2$ dimension was $14 \mathrm{ppm}$. The offset frequency in the $\mathrm{f} 2$ dimension was set to each residual solvent signal. ${ }^{13} \mathrm{C}$-decoupling during acquisition was performed using GARP sequence (pulse length $55 \mu \mathrm{s}$ ). To
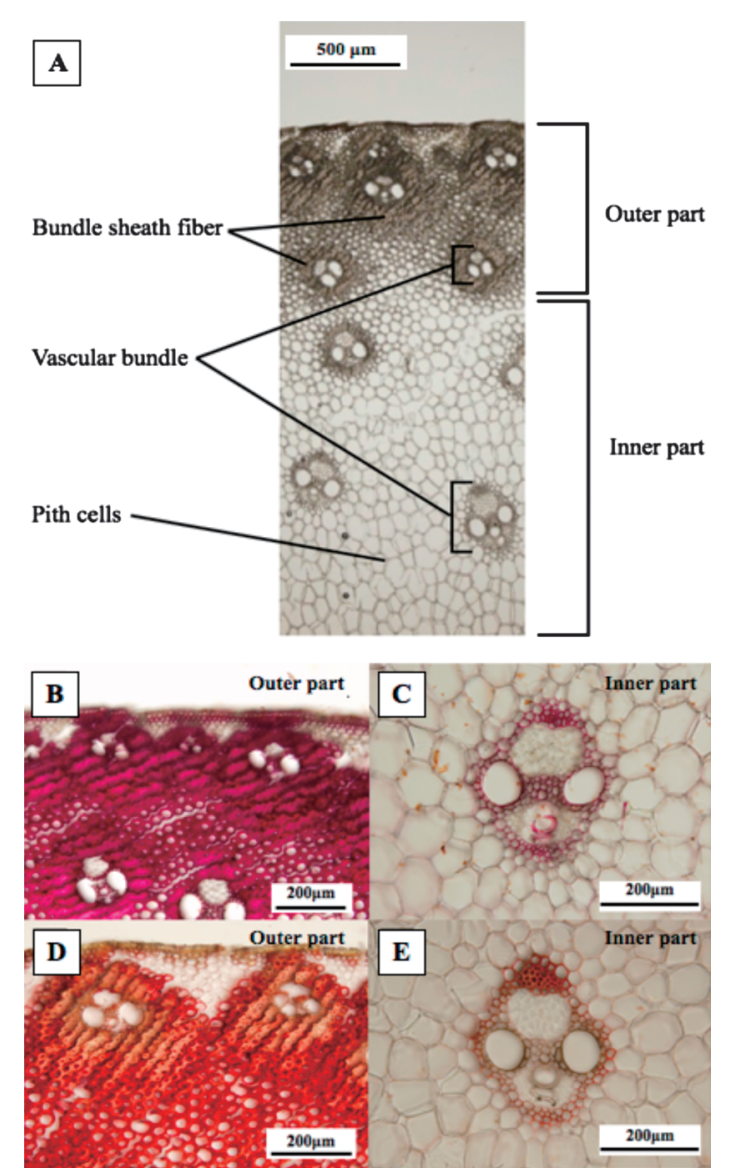

Figure 1. Histochemical analysis of internode of Erianthus arundinaceus. A. Cross-section of the 1st internode of E. arundinaceus. $\mathrm{B}$ and $\mathrm{C}$, phloroglucinol- $\mathrm{HCl}$ reaction. $\mathrm{D}$ and E, Mäule reaction.

normalize the signal intensities in the ${ }^{1} \mathrm{H}-{ }^{13} \mathrm{C}$ HSQC spectra, they were standardized against the noise level of each spectrum.

\section{Results and discussion}

\section{Microscopic observation}

The inner part and outer part of the internode of $E$. arundinaceus differed distinctly in specific gravity and apparent hardness: the outer part was highly dense and very hard compared to the inner part; the densities were $0.07-0.08$ and $0.41-0.48 \mathrm{~g} \mathrm{~cm}^{-3}$ in the inner and outer parts, respectively.

Figure 1A shows the cross-section of the 1st internode of E. arundinaceus. A vascular bundle observed in the outer part was surrounded by bundle sheath fibers with thickened cell-walls, and the vascular bundles were near one another. In contrast, the vascular bundles in the inner part were far apart. In addition, there were few bundle sheath fibers in the inner part, and the pith cells accounted for a substantial area.

To visualize lignin, the cross-section was stained using phloroglucinol-HCl (Figure 1B,C). Red-purple, positive coloration was observed in most of the outer part (Figure $1 \mathrm{~B})$, while that was observed only in bundle sheath fibers 
Table 1. Inorganic elements in ash of Erianthus arundinaceus.

\begin{tabular}{|c|c|c|c|c|}
\hline \multirow{2}{*}{ Elements* } & \multicolumn{2}{|c|}{ Basal internode** } & \multicolumn{2}{|c|}{ Leaf } \\
\hline & Inner part & Outer part & Blade & Sheath \\
\hline $\mathrm{Si}$ & 2802.2 & 4116.3 & 109285.0 & 17306.4 \\
\hline S & 216.4 & 155.5 & 3391.3 & 462.7 \\
\hline K & 2048.3 & 3256.1 & 6113.5 & 2344.7 \\
\hline $\mathrm{Ca}$ & 3527.4 & 3600.6 & 45978.7 & 3509.5 \\
\hline $\mathrm{Ti}$ & 21.9 & 27.8 & 556.1 & 44.9 \\
\hline $\mathrm{Cr}$ & ND & 20.8 & 306.3 & 35.2 \\
\hline $\mathrm{Mn}$ & 26.2 & 25.3 & 1391.1 & 234.5 \\
\hline $\mathrm{Fe}$ & 120.1 & 210.6 & 3789.9 & 271.9 \\
\hline $\mathrm{Ni}$ & 40.1 & ND & ND & ND \\
\hline $\mathrm{Cu}$ & 11.5 & 8.3 & 77.0 & 10.9 \\
\hline $\mathrm{Zn}$ & 183.5 & 89.6 & 181.4 & 25.5 \\
\hline $\mathrm{Rb}$ & 1.7 & 1.6 & ND & ND \\
\hline $\mathrm{Sr}$ & 4.7 & 3.8 & 30.8 & 2.7 \\
\hline Sn & 2.9 & ND & ND & ND \\
\hline
\end{tabular}

$* \mu \mathrm{gg}^{-1}$ cell-wall material. ND, not detected. ** The mixture of the 1 st-5th internodes.

around vascular bundle in the inner part (Figure 1C), indicating that lignin accumulated more abundantly in the outer part compared to the inner part.

Figure 1D and E show the cross-section stained by Mäule reaction, a simple method to distinguish guaiacyl (4-hydroxy-3-methoxyphenyl) from syringyl (3,5-dimethoxy-4-hydroxyphenyl) units in lignin. The former gives brown coloration, while the latter affords red-purple coloration. In the outer part (Figure 1D), the vascular bundle and narrow regions of the bundle sheath fibers surrounding the vascular bundle were stained brown, while most other regions were stained red-purple. In the inner part, the vascular bundle was mainly stained brown with patches of red-purple (Figure 1E). These results strongly suggested the presence of guaiacyl in the vascular bundle sheath and syringyl lignins in the bundle sheath fibers. In addition, the syringyl lignin content in the outer part appeared to be higher than that in the inner part.

\section{Measurement of inorganic elements in ash}

The ash contents of the basal internodes were $0.9 \%$ in the inner and $1.2 \%$ in the outer parts, while those of the leaf were $17.1 \%$ in the blade and $2.4 \%$ in the sheath. Thus, the leaf attached to the basal internodes had the higher ash content than the corresponding basal internodes, consistent with switchgrass, in which the internode and leaves (blade and sheath combined) had $1.6 \%$ and $4.1 \%$ ash, respectively (Hu et al. 2011).

The major inorganic elements in these ashes determined by X-ray fluorescence spectrometry were $\mathrm{Si}$, $\mathrm{Ca}$, and $\mathrm{K}$ (Table 1). In particular, the percentages of $\mathrm{Si}$ in leaf ashes were very high, more than $60 \%$.

\section{Lignin structures of $\mathrm{E}$. arundinaceus}

The GC-MS analysis of the thioacidolysis products showed the presence of phenyltrithioethylpropane<smiles>[R2]c1cc(C([SiH2]C)C(CC)[SiH2]CC)cc([R])c1O</smiles>

$\mathrm{R}_{1}, \mathrm{R}_{2}=\mathrm{H}: p$-Hydroxyphenyltrithioethylpropane $\mathrm{R}_{1}=\mathrm{OMe}, \mathrm{R}_{2}=\mathrm{H}$ : Guaiacyltrithioethylpropane $\mathrm{R}_{1}, \mathrm{R}_{2}=\mathrm{OMe}:$ Syringyltrithioethylpropane

Figure 2. Thioacidolysis products.

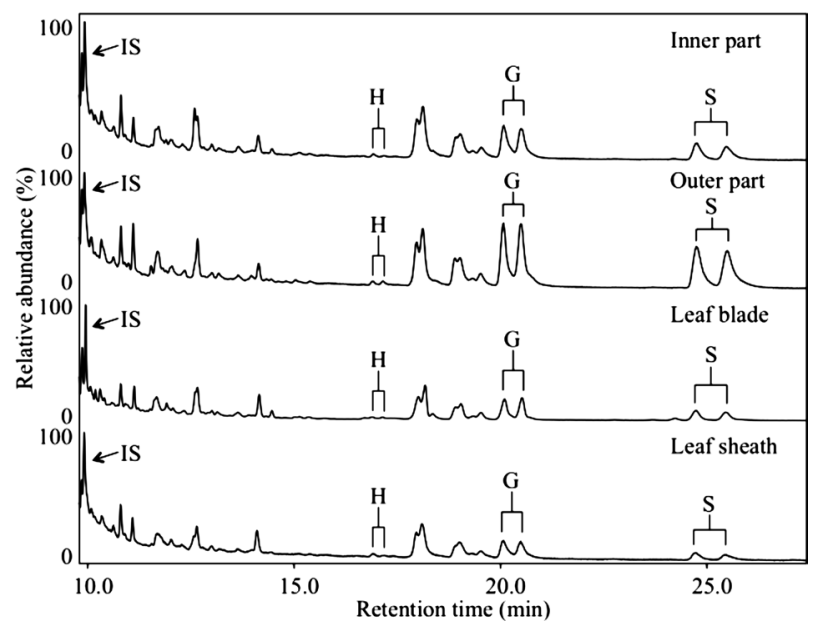

Figure 3. Total ion chromatograms of thioacidolysis products (trimethylsilyl ethers) from four organs of Erianthus arundinaceus in GC-MS analysis. H, G, and S: p-hydroyphenyl-, guaiacyl-, and syringyltrithioethylpropane compounds. The two $\mathrm{H}, \mathrm{G}$, and $\mathrm{S}$ peaks are erythro and threo isomers. IS: internal standard (docosane). Inner part and outer part: the inner and outer parts of 1 st internode, respectively.

compounds (Figure 2), which are derived specifically from $\beta$-O-4 substructures of lignin polymers (Rolando et al. 1992). In addition, the thioacidolysis products 
Table 2. Lignin, p-hydroxycinnamic acids, and enzymatic saccharification efficiency of Erianthus arundinaceus.

\begin{tabular}{|c|c|c|c|c|}
\hline & \multicolumn{2}{|c|}{ 1st internode } & \multicolumn{2}{|c|}{ Leaf } \\
\hline & Inner part & Outer part & Blade & Sheath \\
\hline \multicolumn{5}{|l|}{ Lignin content $(\%)$} \\
\hline Thioglycolic acid method & $23.4 \pm 0.7$ & $28.0^{\mathrm{a}} \pm 0.4$ & $20.7 \pm 0.4$ & $27.1^{\mathrm{a}} \pm 0.5$ \\
\hline Acetyl bromide method & $24.6^{\mathrm{b}} \pm 2.8$ & $26.5^{\mathrm{b}} \pm 1.9$ & $17.2 \pm 3.7$ & $27.5^{\mathrm{b}} \pm 0.6$ \\
\hline \multicolumn{5}{|c|}{ Lignin aromatic components ( $\mu \mathrm{molg}^{-1}$ of cell-wall material) } \\
\hline Vanillin & $438.1^{\mathrm{c}} \pm 7.6$ & $478.4 \pm 15.3$ & $272.9 \pm 8.3$ & $430.9^{c} \pm 9.5$ \\
\hline Syringaldehyde & $266.3 \pm 18.6$ & $378.5 \pm 13.1$ & $124.7 \pm 9.9$ & $185.4 \pm 13.1$ \\
\hline$p$-Hydroxybenzaldehyde & $151.2 \pm 8.5$ & $64.1^{\mathrm{d}} \pm 1.9$ & $55.9^{\mathrm{d}} \pm 5.0$ & $85.6 \pm 6.4$ \\
\hline Vanillic acid & $60.0^{\mathrm{e}} \pm 30.9$ & $44.3^{\mathrm{e}} \pm 8.5$ & $85.0^{\mathrm{e}} \pm 44.8$ & $85.1^{\mathrm{e}} \pm 54.0$ \\
\hline Syringic acid & $17.4^{\mathrm{f}} \pm 1.1$ & $19.4^{\mathrm{f}} \pm 0.8$ & $19.0^{\mathrm{f}} \pm 1.8$ & $19.4^{\mathrm{f}} \pm 1.0$ \\
\hline p-Hydroxybenzoic acid & $70.9^{\mathrm{g}} \pm 2.8$ & $73.1^{\mathrm{g}} \pm 0.9$ & $71.1^{\mathrm{g}} \pm 2.2$ & $70.0^{\mathrm{g}} \pm 4.1$ \\
\hline The molar ratio of S/V & $0.61 \pm 0.04$ & $0.79 \pm 0.03$ & $0.46^{\mathrm{h}} \pm 0.03$ & $0.43^{\mathrm{h}} \pm 0.02$ \\
\hline \multicolumn{5}{|c|}{ Cell-wall-linked cinnamic acids ( $\mathrm{mgg}^{-1}$ of cell-wall material) } \\
\hline Ferulic acid & $9.3 \pm 0.7$ & $7.3 \pm 0.6$ & $11.5^{\mathrm{i} \pm 0.4}$ & $11.8^{\mathrm{i} \pm 0.6}$ \\
\hline$p$-Coumaric acid & $44.7 \pm 1.5$ & $25.7^{\mathrm{j}} \pm 1.9$ & $24.1^{\mathrm{j}} \pm 0.8$ & $28.8^{\mathrm{j}} \pm 0.5$ \\
\hline \multicolumn{5}{|c|}{ Enzymatic saccharification efficiency (\%) } \\
\hline Reaction time $24 \mathrm{~h}$ & $10.4^{\mathrm{k}} \pm 0.3$ & $10.0^{\mathrm{k}} \pm 1.6$ & $21.6 \pm 1.5$ & $15.2 \pm 0.8$ \\
\hline
\end{tabular}

S/V: syringaldehyde/vanillin. Data with the same letter are not statistically different (Tukey's test). Data are mean values \pm standard deviations. Number of replicates $(n=3)$.

from all four organs comprised guaiacyl, syringyl and p-hydroxyphenyl compounds, indicating that lignins of all organs consisted of guaiacyl, syringyl, and $p$ hydroxyphenyl units (Figure 3). The peak heights of $p$ hydroxyphenyltrithioethyl propane compounds are much smaller than those of guaiacyl and syringyl compounds (Figure 3), in accordance with the results reported for rice and wheat (Rolando et al. 1992).

To determine the lignin aromatic components not only of $\beta-O-4$ substructure which is obtained by the thioacidolysis but also of other substructures, each organ was analysed by the microscale nitrobenzene oxidation method (Yamamura et al. 2010, 2011). The GC-MS analysis of the nitrobenzene oxidation products showed that lignin in each organ consisted of guaiacyl, syringyl, and $p$-hydroxyphenyl units (Table 2), consistent with the result of thioacidolysis. The ratios of syringaldehyde to vanillin $(\mathrm{S} / \mathrm{V})$, which indicate the ratios of syringyl to guaiacyl lignins, were 0.61 in the inner part and 0.79 in the outer part (Table 2); the higher $\mathrm{S} / \mathrm{V}$ ratio in the outer than the inner part was consistent with the results of the Mäule reaction (Figure 1D, E; Table 2, Tukey's test, $p<0.05)$. The $\mathrm{S} / \mathrm{V}$ value of the 1 st internode was higher than those of the leaf blade (0.46) and sheath (0.43) (Table 2, Tukey's test, $p<0.05$ ). The values were higher than in stems of other large gramineous plants [e.g., 0.27 in sorghum (Dzhumanova and Dalimova 2011), $0.43-0.56$ in switchgrass (Jung and Vogel 1992), and 0.37-0.59 in Miscanthus (Sarkanen and Hergert 1971)], and similar to those in small gramineous plants [e.g., 0.48-0.89 in rice straw (Dalimova and Abduazimov 1994; Dzhumanova and Dalimova 2011), and 0.72-0.93 in wheat straw (Dalimova and Abduazimov 1994)].

\section{NMR analysis of $\mathrm{E}$. arundinaceus lignocellulose}

$E$. arundinaceus samples from different organs were analysed by 2D-NMR, and typical HSQC spectrum from the outer part of the 1st internode is shown in Figure 4. Carbohydrate signals were predominant in the spectrum, and they include correlations in the range $\delta_{\mathrm{C}} l$ $\delta_{\mathrm{H}} 60-85 / 2.5-5.5$, which partially overlapped with lignin signals, while the anomeric correlations in the range $\delta_{\mathrm{C}} /$ $\delta_{\mathrm{H}} 90-110 / 3.5-6.0$ were well-resolved. Lignin signals were also clearly observed in the HSQC spectrum. These lignin and carbohydrate contours in the HSQC spectra were assigned by comparison with the previous report (Kim and Ralph 2010). From the averaged HSQC signal intensities within lignocellulose residues (Table 3), we can calculate how these residues are distributed in terms of NMR profiles.

The HSQC-determined abundances of the $p$ hydroxyphenyl $(H)$, guaiacyl $(G)$ and syringyl (S) lignin units in the outer part are higher than in the inner part, which coincide well with the lignin quantitation by wet chemistry; the lignin content in the outer part is higher than in the inner part (Table 2). In addition, the syringyl/guaiacyl (S/G) ratios by HSQC analysis (Table 3 ) were in close agreement with the $S / V$ ratios obtained by nitrobenzene oxidation (Table 2). With respect to the different lignin substructures (intermonomer linkage types), all the lignins showed a predominance of $\beta$-O4 units (A; $64-71 \%$ HSQC intensities of total observed side-chains), followed by $\beta-5$ phenylcoumaran-type units (B; $7-16 \%$ HSQC intensities), lower amounts of $\beta-\beta$ resinol-type (C; 3-9\% HSQC intensities) and 5-5/4$O-\beta$ dibenzodioxocin-type units $(\mathrm{D} ; 13-19 \%$ HSQC intensities). The spirodienone $\beta$-1 structure (Kim and Ralph 2010) was not observed under our experimental 


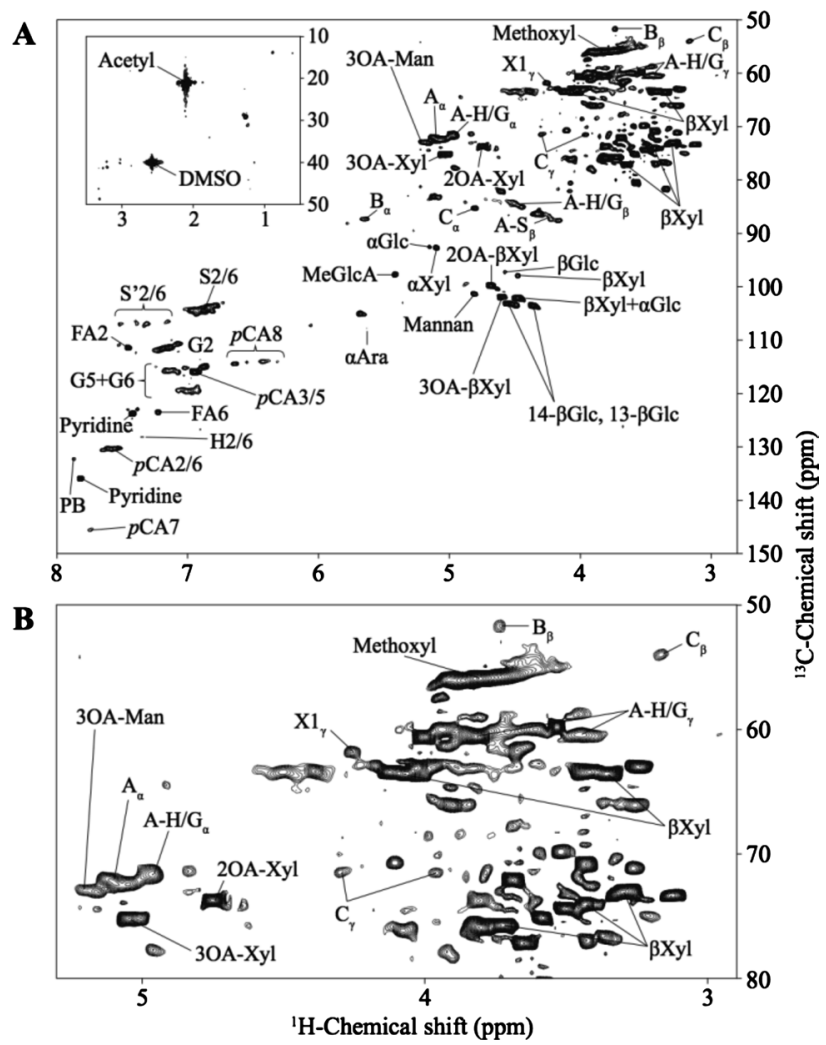

Figure 4. ${ }^{1} \mathrm{H}-{ }^{13} \mathrm{C}$ HSQC spectrum of the cell-wall fraction of the outer internode of Erianthus arundinaceus. $(\mathrm{A}) \delta_{\mathrm{C}} / \delta_{\mathrm{H}} 50-150 / 2.8-8.0 .(\mathrm{B})$ Expanded aliphatic regions, $\delta_{\mathrm{C}} / \delta_{\mathrm{H}} 50-80 / 2.9-5.3$. Annotations were coded according to Kim and Ralph (2010). Abbreviations are defined in Table 4.

condition.

The HSQC spectra also reveal differences in the carbohydrates among E. arundinaceus organs, which are observed in two differentiated regions of the spectra: the oxygenated-aliphatic region and the region corresponding to the anomeric correlations (Figure 4). The oxygenated-aliphatic region shows signals from $O$ acetylated xylans (3-O-acetyl- $\beta$-D-xylopyranoside, and 2 -O-acetyl- $\beta$-D-xylopyranoside units) and $O$-acetylated mannans (2-O-acetyl- $\beta$-D-mannopyranoside). Other signals in this region correspond to $\mathrm{C} 2-\mathrm{H} 2, \mathrm{C} 3-$ $\mathrm{H} 3, \mathrm{C} 4-\mathrm{H} 4$ and $\mathrm{C} 5-\mathrm{H} 5$ correlations of xylans $(\beta-\mathrm{D}-$ xylopyranoside unit), which overlap with unassigned cross-signals of pentose and hexose units of other polysaccharides. However, well-resolved $\mathrm{C} 1-\mathrm{H} 1$ correlation signals in the anomeric region, which are also listed in Table 3, are observed. Cross-signals from arabinans, mannans, galactans, xylans and glucans including non-crystalline cellulose, as well as signals from $O$-acetylated mannans and xylans, and from the 4-O-methyl- $\alpha$-D-glucuronic acid are readily apparent and well resolved in this region of the spectra. Both $\beta$-Dglucopyranoside and $\beta$-D-xylopyranoside, composing major backbone carbohydrates, are rich in internode outside, whereas $\beta$-D-mannopyranoside and $O$-acetylated sugars, might be contributed to branching carbohydrates, are abundant in internode inside. The higher contents of structural polysaccharide-derived $\beta$-D-glucopyranoside and $\beta$-D-xylopyranoside in the outer part of the 1 st internode accord well with its function of mechanical support. Arabinose and galactose polymers are often associated to pectins. Therefore, the high amounts of these sugars, together with methyl galacturonate, in the internode inside sample may reflect the higher content of pectin (Coetzze and Wolfaart 2010).

\section{Lignin contents of $\mathrm{E}$. arundinaceus}

The thioglycolic acid method showed that lignin contents of the 1st internode were 23.4 and $28.0 \%$ in the inner and the outer parts, respectively. Those of leaf blade and sheath were $20.7 \%$ and $27.1 \%$, respectively (Table 2 ). In addition, lignin contents determined by the acetyl bromide method were $24.6 \%$ in the inner part and $26.5 \%$ in the outer part, while those in leaf blade and leaf sheath were 17.2 and $27.5 \%$, respectively (Table 2 ). Lignin contents determined by the two methods gave almost identical values.

The 1st internode of E. arundinaceus had a high lignin content, higher than those of small gramineous plants [e.g., 6.4-19.0\% in rice straws (Deng et al. 2007; Hattori et al. 2012; Jin and Chen 2006; Sangnark and Noomhorm 2004; Suzuki et al. 2009), 5.3-17.9\% in wheat straws (Hongzhang and Liying 2007; Papatheofanous et al. 1998; Saha et al. 2005; Xu et al. 2006), and $15-21 \%$ in corn 
Table 3. Comparison of cross peak signal intensities (a.u.) in ${ }^{1} \mathrm{H}-{ }^{13} \mathrm{C}$ HSQC spectra of four kinds of organs of Erianthus arundinaceus.

\begin{tabular}{|c|c|c|c|c|}
\hline & \multicolumn{2}{|c|}{ 1st internode } & \multicolumn{2}{|c|}{ Leaf } \\
\hline & Inner & Outer & Blade & Sheath \\
\hline \multicolumn{5}{|l|}{ Lignin } \\
\hline S & 77.4 & 168.3 & 42.7 & 44.7 \\
\hline G & 150.8 & 236.6 & 106.0 & 99.3 \\
\hline $\mathrm{H}$ & 6.3 & 8.3 & 6.9 & 6.9 \\
\hline $\mathrm{FA}$ & 62.8 & 68.3 & 44.1 & 43.2 \\
\hline$p \mathrm{CA}$ & 440.0 & 293.1 & 176.5 & 201.0 \\
\hline $\mathrm{PB}$ & 5.5 & 6.8 & 4.8 & 4.3 \\
\hline $\mathrm{X} 1$ & 13.6 & 22.4 & 11.0 & 11.5 \\
\hline A & 69.4 & 118.6 & 36.2 & 32.0 \\
\hline $\mathrm{A}-\mathrm{H} / \mathrm{G}$ & 295.1 & 422.9 & 224.1 & 208.5 \\
\hline A-S & 24.3 & 11.2 & 19.4 & 9.2 \\
\hline B & 41.6 & 21.0 & 24.1 & 24.4 \\
\hline $\mathrm{C}$ & 6.9 & 27.3 & 6.8 & 4.8 \\
\hline $\mathrm{D}$ & 34.0 & 42.2 & 37.2 & 28.0 \\
\hline Methoxyl & 243.8 & 345.9 & 165.4 & 161.6 \\
\hline $\mathrm{S} / \mathrm{G}$ ratio & 0.51 & 0.71 & 0.40 & 0.45 \\
\hline \multicolumn{5}{|l|}{ Carbohydrate } \\
\hline$\beta$-D-Glcp & 232.3 & 259.7 & 171.0 & 167.8 \\
\hline$\alpha$-D-Glcp & 11.9 & 9.0 & 7.1 & 7.4 \\
\hline$\beta$-D-Xylp & 1795.1 & 2286.0 & 1647.7 & 1591.3 \\
\hline$\alpha$-D-Xylp & 14.6 & 16.6 & 17.1 & 13.1 \\
\hline 2-O-Ac-Xylp & 649.1 & 617.5 & 382.4 & 366.3 \\
\hline 3-O-Ac-Xyl $p$ & 240.8 & 258.5 & 146.1 & 217.6 \\
\hline$\alpha$-D-Man $p$ & 2.5 & 3.3 & 1.8 & 2.3 \\
\hline 2-O-Ac-Man $p$ & 2.7 & 3.7 & 2.4 & 3.4 \\
\hline 3-O-Ac-Man $p$ & 18.7 & 15.5 & 6.0 & 8.3 \\
\hline Mannan & 17.0 & 15.9 & 8.4 & 8.3 \\
\hline$\beta$-D-Gal $p$ & 6.1 & 3.6 & 4.1 & 4.4 \\
\hline$\alpha$-L-Araf & 17.6 & 11.8 & 20.8 & 10.6 \\
\hline$\alpha$-L-Fucp & 31.2 & 6.0 & 11.5 & 8.8 \\
\hline MeGlcA & 35.2 & 24.4 & 11.8 & 14.5 \\
\hline Acetyl & 506.5 & 473.4 & 302.5 & 305.6 \\
\hline
\end{tabular}

Abbreviations as in Table 4. a.u.: arbitrary unit.

stover (Buranov and Mazza 2008)]. The lignin content was similar to that in other large gramineous plants [e.g., 17.4-28.5\% in Miscanthus (Higuchi et al. 1967a; Ververis et al. 2004), and 19.5-36.0\% in switchgrass (Hurter 1997; Law et al. 2001; Madakadze et al. 1999)]. The lignin contents of the outer part of the 1st internode and the leaf sheath were equal to that of a conifer (2433\%; Sarkanen and Hergert 1971). Thus, both the outer internode and the leaf sheath may help to support mechanically the heavy body of a large Erianthus plant.

\section{Cell-wall-bound p-hydroxycinnamates}

The amounts of the cell-wall-linked $p$-hydroxycinnamic acids, ferulic and $p$-coumaric acids, were measured (Table 2). Amounts of ferulic acid in the 1st internode were 9.3 and $7.3 \mathrm{mg} \mathrm{g}^{-1}$ cell-wall material in the inner and outer parts, respectively. On the other hand, those in the leaves were 11.5 and $11.8 \mathrm{mgg}^{-1}$ cell-wall material in the blade and sheath, respectively. Amounts of $p$-coumaric acid were 44.7 and $25.7 \mathrm{mg} \mathrm{g}^{-1}$ cell-wall material in the inner and the outer parts of the internode, respectively, while those in the leaf blade and sheath were 24.1 and $28.8 \mathrm{mg} \mathrm{g}^{-1}$ cell-wall material, respectively. As in our results on E. arundinaceus, the amount of $p$-coumaric acid was higher than that of ferulic acid in Miscanthus stem (Higuchi et al. 1967a, 1967b) and sorghum (Hatfield et al. 1999b). However, the levels of p-coumaric acid were lower than that of ferulic acid in wheat, rice, rye, and barley straws (Iiyama et al. 1990; Sun et al. 2001), suggesting that the compositions of lignins, polysaccharides, and $p$-hydroxycinnamic acids differ between large gramineous plants, such as Erianthus and Miscanthus, and small gramineous plants, such as wheat and rye.

\section{Enzymatic saccharification efficiency}

In general, it is known that there is a large amount of starch in the cell of gramineous plants. Thus, we removed the starch in E. arundinaceus samples before the saccharification analyses. However, there was only trace amount of starch in each organ of E. arundinaceus (data not shown). 
Table 4. Abbreviations of compounds in the NMR analysis.

\begin{tabular}{|c|c|}
\hline Abbreviations & Compounds \\
\hline S & syringyl \\
\hline$S^{\prime}$ & syringyl (oxidized $\alpha$-ketone) \\
\hline G & guaiacyl \\
\hline $\mathrm{G}^{\prime}$ & guaiacyl (oxidized $\alpha$-ketone) \\
\hline $\mathrm{H}$ & $p$-hydroxyphenyl \\
\hline A & $\beta$-ether $(\beta-O-4)$ \\
\hline A-S & $\beta-O-4-S$ \\
\hline A-H/G & $\beta-O-4-\mathrm{H} / \mathrm{G}$ \\
\hline B & phenylcoumaran $(\beta-5)$ \\
\hline $\mathrm{C}$ & resinol $(\beta-\beta)$ \\
\hline $\mathrm{D}$ & dibenzodioxocin $(5-5 / 4-O-\beta)$ \\
\hline $\mathrm{X} 1$ & cinnamyl alcohol end group \\
\hline FA & ferulate \\
\hline$p \mathrm{CA}$ & $p$-coumarate \\
\hline $\mathrm{PB}$ & $p$-hydroxybenzoate \\
\hline Glcp & glucopyranoside \\
\hline$\alpha \mathrm{Glc}$ & $\alpha$-D-Glcp \\
\hline$\beta \mathrm{Glc}$ & $\beta$-D-Glcp \\
\hline $14-\beta \mathrm{Glc}$ & $(1 \rightarrow 4)-\beta$-D-Glc $p$ \\
\hline $14-\beta$ Glc, $13-\beta$ Glc & $(1 \rightarrow 4)-\beta-\mathrm{D}-\mathrm{Gl} c p[\&(1 \rightarrow 3)-\beta-\mathrm{D}-\mathrm{Gl} c p]$ \\
\hline $\mathrm{Xyl} p$ & xylopyranoside \\
\hline$\alpha \mathrm{Xyl}$ & $\alpha$-D-Xylp \\
\hline$\beta$ Xyl & $\beta$-D-Xylp \\
\hline$\beta \mathrm{Xyl}+\alpha \mathrm{Glc}$ & $\beta-\mathrm{D}-\mathrm{Xyl} p+\alpha-\mathrm{D}-\mathrm{Gl} c p$ \\
\hline Ac & acetylated \\
\hline 2OA-Xyl & 2-O-Ac-Xylp \\
\hline 3OA-Xyl & 3-O-Ac-Xylp \\
\hline $2 \mathrm{OA}-\beta \mathrm{Xyl}$ & $2-O-A c-\beta-\mathrm{D}-\mathrm{Xyl} p$ \\
\hline $3 \mathrm{OA}-\beta \mathrm{Xyl}$ & 3-O-Ac- $\beta$-D-Xylp \\
\hline $\operatorname{Man} p$ & Mannopyranoside \\
\hline 3OA-Man & 3-O-Ac-Man $p$ \\
\hline Araf & arabinofuranoside \\
\hline$\alpha$ Ara & $\alpha$-L-Araf \\
\hline Fucp & fucopyranoside \\
\hline Galp & galactopyranoside \\
\hline GlcA & glucuronic acid \\
\hline $\mathrm{Me}$ & methyl \\
\hline MeGlcA & 4-O-methyl- $\alpha$-D-glucuronic acid \\
\hline DMSO & dimethyl sulfoxide \\
\hline
\end{tabular}

Figure 5 shows a time-course of enzymatic saccharification efficiencies for each organ. The efficiencies after $24 \mathrm{~h}$ reaction for the inner and the outer internodes were 10.4 and $10.0 \%$, respectively, while those of the leaf blade and leaf sheath were 21.6 and $15.2 \%$, respectively (Table 2 ). The leaf had higher enzymatic saccharification efficiency than the 1st internode (Tukey's test, $p<0.05$ ).

Lignin is known to inhibit the enzymatic saccharification process (Li et al. 2008), and an inverse correlation exists between lignin contents and enzymatic saccharification efficiencies. That is, a sample with low lignin content indicates a high enzymatic saccharification efficiency. For example, rice mutant lines in a series of genes encoding enzymes in the cinnamate/monolignol pathway for lignin showed lower lignin contents and higher enzymatic saccharification efficiencies (Hattori

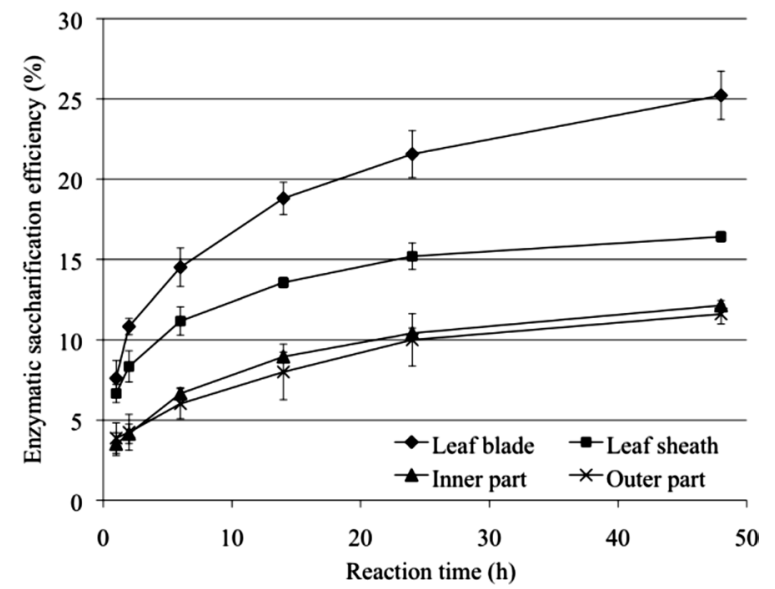

Figure 5. Time courses of enzymatic saccharification efficiencies of four Erianthus arundinaceus organs. Error bar: standard deviation $(n=3)$.

et al. 2012). In addition, alfalfa mutant lines with downregulated 4-hydroxycinnamate 3 -hydroxylase $(\mathrm{C} 3 \mathrm{H})$ and hydroxycinnamoyl transferase (HCT), enzymes in the cinnamate/monolignol pathway, had low lignin contents and almost twice the enzymatic saccharification efficiencies of the controls (Chen and Dixon 2007). This trend was found in all organs of E. arundinaceus except the inner internode. Despite the obvious difference in lignin contents between the inner and outer parts, the inner part had almost the same enzymatic saccharification efficiency as the outer part (Table 2), indicating that not only lignin but also other factors affected enzymatic saccharification in the inner part.

In addition to lignins, ferulate crosslinks are also known to inhibit the enzymatic saccharification (Grabber et al. 1998a, 1998b). Although the amount of ferulic acid in the leaf, which was liberated as ferulic acid monomer by moderate alkaline hydrolysis, was higher than in the 1st internode, the enzymatic saccharification efficiency of the leaf was higher than that of the 1st internode. Further studies remain to be done with respect to the effects of the crosslinks by ferulate dimer structures on saccharification efficiencies.

In this study, we showed that the characteristics of lignocellulose and enzymatic saccharification efficiencies varied substantially among organs of E. arundinaceus. Saccharification efficiencies were determined using $E$. arundinaceus samples without any pretreatment so that lignocellulose of the sample itself was characterized. For practical use, pretreatment such as alkaline treatment would be effective, as recently reported for Erianthus sp. (Horikawa et al. 2012).

\section{Conclusions}

We characterized Erianthus arundinaceus in terms of lignins, $p$-hydroxycinnamic acids, enzymatic 
saccharification efficiencies, and minerals in the ash of the inner and outer parts of the internode and the leaf blade and sheath. The outer part of the internode had the high lignin content, and the lignin was rich in syringyl unit in comparison with other organs. The inner part of the internode did not show a negative correlation between lignin contents and enzymatic saccharification efficiencies, suggesting that enzymatic saccharification of inner part was reduced by not only lignin but also other factors. Of the four organs, the leaf blade had the highest enzymatic saccharification efficiency after $24 \mathrm{~h}$ and the highest ash content and silicon was the majority. This study can provide fundamental data on a large gramineous plants.

\section{Acknowledgements}

We thank Kamigamo Experimental Station, Field Science Education and Research Center (FSERC), Kyoto University, Japan, for providing E. arundinaceus plants. We thank Ms. Mai Mukai, Ms. Keiko Tsuchida, and Ms. Midori Koda for technical assistance, Drs. Masahiro Sakamoto and Hiroshi Kamitakahara for experimental support of the ash and inorganic element measurements. This research was partly supported by the grant "Research and development of genetic and metabolic information of energy producing plants for breeding programs" from the New Energy and Industrial Technology Development Organization (NEDO) and by Grants-in-Aid for Scientific Research from the Japan Society for Promotion of Science (Nos. 20380102, and 23658144). A part of this study was conducted using the Forest Biomass Analytical System (FBAS), Research Institute for Sustainable Humanosphere, Kyoto University.

\section{References}

Amalraj VA, Balasundaram N (2006) On the taxonomy of the members of 'Saccharum complex'. Genet Resour Crop Evol 53: $35-41$

Amalraj VA, Rakkiyappan P, Neelamathi D, Chinnaraj S, Subramanian S (2008) Wild cane as a renewable source for fuel and fibre in the paper industry. Curr Sci 95: 1599-1602

Anderson WF, Akin DE (2008) Structural and chemical properties of grass lignocelluloses related to conversion for biofuels. $J$ Ind Microbiol Biotechnol 35: 355-366

Balat M, Blat H (2009) Recent trend in global production and utilization of bio-ethanol fuel. Appl Energy 86: 2273-2282

Boerjan W, Ralph J, Baucher M (2003) Lignin biosynthesis. Annu Rev Plant Biol 54: 519-546

Buranov AU, Mazza G (2008) Lignin in straw of herbaceous crops. Ind Crops Prod 28: 237-259

Chen F, Dixon RA (2007) Lignin modification improves fermentable sugar yields for biofuel production. Nat Biotechnol 25: 759-761

Coetzze B, Wolfaart F(2010) Pectic monosaccharides and total pectin content of two Eucalyptus spp. In 1st Symposium on Biotechnology Applied to Lignocelluloses: LignoBiotech-One. INRA, Reims, France, p 141

Dalimova GN, Abduazimov KA (1994) Lignins of herbacelus plants. Chem Nat Compd 30: 146-159

Deng L, Wang Y, Zhang Y, Ma R (2007) The enhancement of ammonia pretreatment on the fermentation of rice straw hydrolysate to xylitol. J Food Biochem 31: 195-205

Dzhumanova ZK, Dalimova GN (2011) Nitrobenzene oxidation of lignins from several plants of the family Gramineae. Chem Nat Compd 47: 419-421

Fujii Y, Azuma J, Okamura K (1993) Distribution of lignin and esterified phenolic acids in vasucular bundle of elongating internode of bamboo. Bamboo J 11: 41-53

Grabber JH, Hatfield RD, Ralph J (1998a) Diferulate cross-links impede the enzymatic degradation of non-lignified maize walls. J Sci Food Agric 77: 193-200

Grabber JH, Ralph J, Hatfield RD (1998b) Ferulate cross-links limit the enzymatic degradation of synthetically lignified primary walls of maize. J Agric Food Chem 46: 2609-2614

Guo D, Chen F, Wheeler J, Winder J, Selman S, Peterson M, Dixon RA (2001) Improvement of in-rumen digestibility of alfalfa forage by genetic manipulation of lignin $O$-methyltransferases. Transgenic Res 10: 457-464

Hatfield RD, Grabber J, Ralph J, Brei K (1999a) Using the acetyl bromide assay to determine lignin concentrations in herbaceous plants: some cautionary notes. J Agric Food Chem 47: 628-632

Hatfield RD, Wilson JR, Mertens DR (1999b) Composition of cell walls isolated from cell types of grain sorghum stems. J Sci Food Agric 79: 891-899

Hattori T, Morita S (2010) Energy crops for sustainable bioethanol production; which, where and how? Plant Prod Sci 13: 221-234

Hattori T, Murakami S, Mukai M, Yamada T, Hirochika H, Ike M, Tokuyasu K, Suzuki S, Sakamoto M, Umezawa T (2012) Rapid analysis of transgenic rice straw using near-infrared spectroscopy. Plant Biotechnol 29: 359-366

Hattori T, Shiotsu F, Doi T, Morita S (2010) Suppression of tillering in Erianthus ravennae (L.) Beauv. Due to drought stress at establishment. Plant Prod Sci 13: 252-255

Higuchi T, Ito Y, Kawamura I (1967a) p-Hydroxyphenylpropane component of Grass lignin and role of tyrosine-ammonia lyase in its formation. Phytochemistry 6: 875-881

Higuchi T, Ito Y, Shimada M, Kawasaki I (1967b) Chemical properties of milled wood lignin of grasses. Phytochemistry 6: 1551-1556

Hongzhang C, Liying L (2007) Unpolluted fractionation of wheat straw by steam explosion and ethanol extraction. Bioresour Technol 98: 666-676

Horikawa Y, Imai T, Takada R, Watanabe T, Takabe K, Kobayashi Y, Sugiyama J (2012) Chemometric analysis with near-infrared spectroscopy for chemically pretreated Erianthus toward efficient bioethanol production. Appl Biochem Biotechnol 166: 711-721

Hu Z, Foston MB, Ragauskas AJ (2011) Biomass characterization of morphological portions of alamo switchgrass. J Agric Food Chem 59: 7765-7772

Hurter RW(1997) Nonwood Plant Fiber Characteristics. In: Agricultural Residues. TAPPI Nonwood Fibers Short Course Notes

Iiyama K, Lam TBT, Stone B (1990) Phenolic acid bridges between polysaccharides and lignin in wheat internodes. Phytochemistry 29: 733-737

Jackson P, Henry RJ(2011) Erianthus. In: Kole C (ed) Wild Crop Relatives: Genomic and Breeding Resources, Industrial Crops. Springer, Berlin, pp 97-107

Jin S, Chen H (2006) Structural properties and enzymatic hydrolysis of rice straw. Process Biochem 41: 1261-1264

Jung H-JG, Vogel KP (1992) Lignification of switchgrass (Panicum virgatum) and big bluestem (Andropogon gerardii) plant parts 
during maturation and its effect on fibre degradability. J Sci Food Agric 59: 169-176

Kim H, Ralph J (2010) Solution-state 2D NMR of ball-milled plant cell wall gels in DMSO- $d_{6} /$ pyridine- $d_{5}$. Org Biomol Chem 8: 576-591

Law KN, Kokta BV, Mao CB (2001) Fibre morphology and sodasulphite pulping of switchgrass. Bioresour Technol 77: 1-7

Li X, Weng J-K, Chapple C (2008) Improvement of biomass through lignin modification. Plant J 54: 569-581

Madakadze IC, Radiotis T, Li J, Goel K, Smith DL (1999) Kraft pulping characteristics and pulp properties of warm season grasses. Bioresour Technol 69: 75-85

Martone PT, Estevez JM, Lu F, Ruel K, Denny MW, Somerville C, Ralph J (2009) Discovery of lignin in seaweed reveals convergent evolution of cell-wall architecture. Curr Biol 19: 169-175

Matsuo K, Chuenpreecha T, Matsuo N, Ponragdee W (2002) Ecophysiological characteristics of Erianthus spp. and yielding abilities of three forages under conditions of cattle feces application. JIRCAS Working Rep 30: 187-194

Mislevy P, Martin FG, Adjei MB, Miller JD (1997) Harvest management effects on quantity and quality of Erianthus plant morphological components. Biomass Bioenergy 13: 51-58

Nair NV, Selvi A, Sreenivasan TV, Pushpalatha KN, Mary S (2005) Molecular diversity among Saccharum, Erianthus, Sorghum, Zea and their hybrids. Sugar Tech 7: 55-59

Nakatsubo T, Kitamura Y, Sakakibara N, Mizutani M, Hattori T, Sakurai N, Shibata D, Suzuki S, Umezawa T (2008) At5g54160 gene encodes Arabidopsis thaliana 5-hydroxyconiferaldehyde $O$ methyltransferase. J Wood Sci 54: 312-317

Papatheofanous MG, Billa E, Koullas DP, Monties B, Koukios EG (1998) Optimizing multisteps mechnical-chemical fractionation of wheat straw components. Ind Crops Prod 7: 249-256

Park JY, Seyama T, Shiroma R, Ike M, Srichuwong S, Nagata K, Arai-Sanoh Y, Kondo M, Tokuyasu K (2009) Efficient recovery of glucose and fructose via enzymatic saccharification of rice straw with soft carbohydrates. Biosci Biotechnol Biochem 73: 1072-1077

Rolando C, Monties B, Lapierre C(1992) Thioacidolysis. In: Lin SY, Dence CW (eds) Methods in Lignin Chemistry. Springer, Berlin, pp 334-349

Saha BC, Iten LB, Cotta MA, Wu YV (2005) Dilute acid pretreatment, enzymatic saccharification and fermentation of wheat straw to ethanol. Process Biochem 40: 3693-3700

Sakakibara N, Suzuki S, Umezawa T, Shimada M (2003)
Biosynthesis of yatein in Anthriscus sylvestris. Org Biomol Chem 1: 2474-2485

Sangnark A, Noomhorm A (2004) Chemical, physical and baking properties of dietary fiber prepared from rice straw. Food Res Int 37: 66-74

Sarkanen KV, Hergert HL (1971) Classification and distribution. In: Sarkanen KV, Ludwig CH (eds) Lignins: Occurrence, formation, structure and reactions. John Wiley and Sons, Inc., New York, pp 43-94

Sun R-C, Sun X-F, Zhang S-H (2001) Quantitative determination of hydroxycinnamic acids in wheat, rice, rye, and barley straws, maize stems, oil palm frond fiber, and fast-growing poplar wood. J Agric Food Chem 49: 5122-5129

Suzuki S, Suzuki Y, Yamamoto N, Hattori T, Sakamoto M, Umezawa T (2009) High-throughput determination of thioglycolic acid lignin from rice. Plant Biotechnol 26: 337-340

Tagane S, Terajima Y, Shikina Y, Kyan M, Makiya N, Irei S, Yamato K, Sugimoto A (2011) Effects of day-length treatment and Harvesting time on the flowering of Erianthus arundinaceus on Ishigaki island, Japan. Trop Agr Develop 55: 44-50

Umezawa T (2010) The cinnamate/monolignol pathway. Phytochem Rev 9: 1-17

Uwatoko N, Tanaka M, Saito A, Gau M (2011) Establishment of plant regeneration system in Erianthus arundinaceus (Retz.) Jeswiet, a potential biomass crop. Grassland Science 57: 231-237

Ververis C, Georghiou K, Christodoulakis N, Santas P, Santas R (2004) Fiber dimentions, lignin and cellulose content of various plant materials and their suitability for paper production. Ind Crops Prod 19: 245-254

Wada M, Ike M, Tokuyasu K (2010) Enzymatic hydrolysis of cellulose I is greatly accelerated via its conversion to the cellulose II hydrate form. Polym Degrad Stabil 95: 543-548

Xu F, Sun J-X, Sun RC, Fowler P, Baird MS (2006) Comparative study of organosolv lignins from wheat straw. Ind Crops Prod 23: 180-193

Yamamura M, Hattori T, Suzuki S, Shibata D, Umezawa T (2010) Microscale alkaline nitrobenzene oxidation method for highthroughput determination of lignin aromatic components. Plant Biotechnol 27: 305-310

Yamamura M, Wada S, Sakakibara N, Nakatsubo T, Suzuki S, Hattori T, Takeda M, Sakurai N, Suzuki H, Shibata D, Umezawa $\mathrm{T}$ (2011) Occurrence of guaiacyl/p-hydroxyphenyl lignin in Arabidopsis thaliana T87 cells. Plant Biotechnol 28: 1-8 